\title{
Effect of Soybean Seeds On Some Physiological And Biochemical Parameters In Ovariectomized Rats
}

\author{
A. A. Hassan $\quad$ E. M. Abdulrasool H. M. Jassim \\ Department of physiology / College of Veterinary Medicine \\ University of Mosul, Mosul,Iraq
}

Received

$21 / 10 / 2009$
Accepted

$10 / 12$ / 2009

\section{الخلاصة}

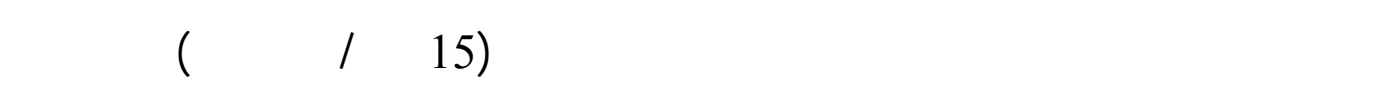

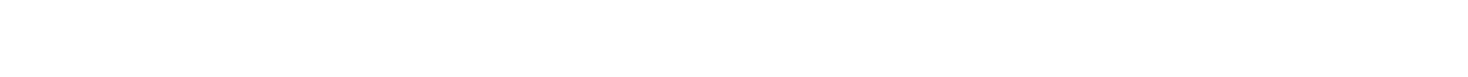

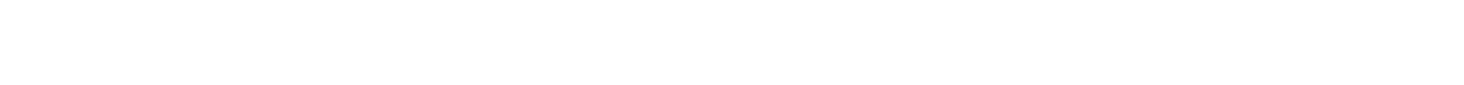

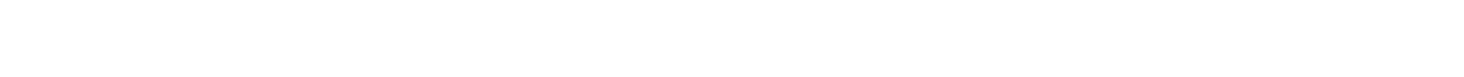

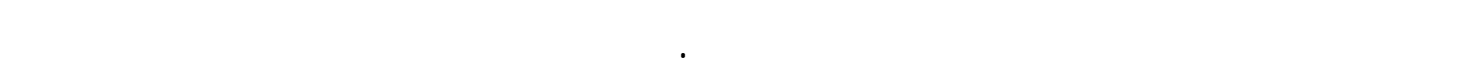

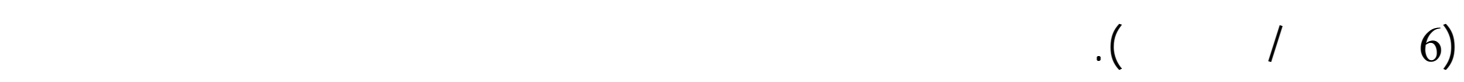

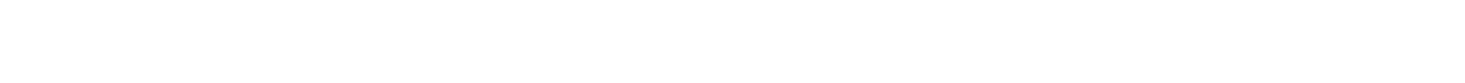

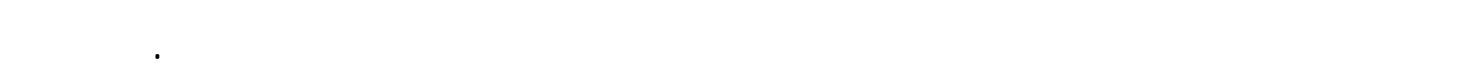

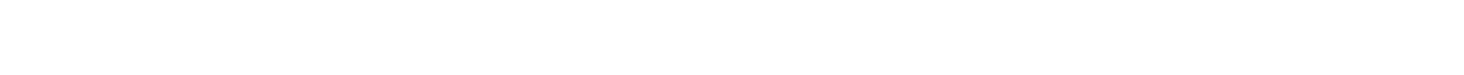

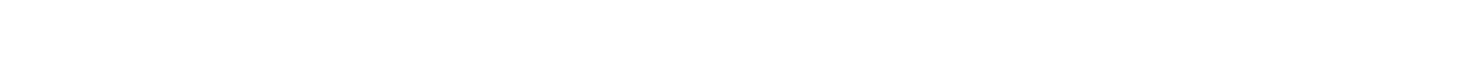

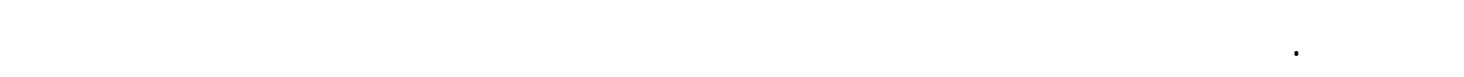

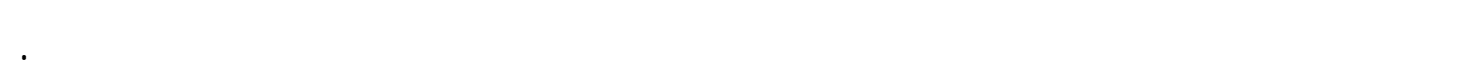

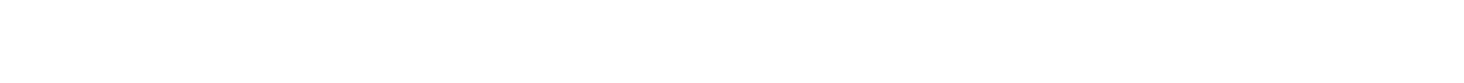

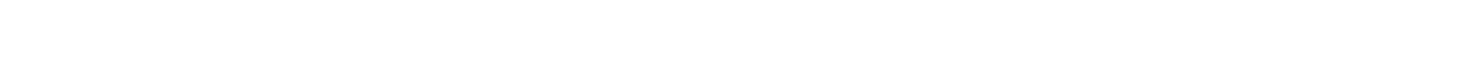

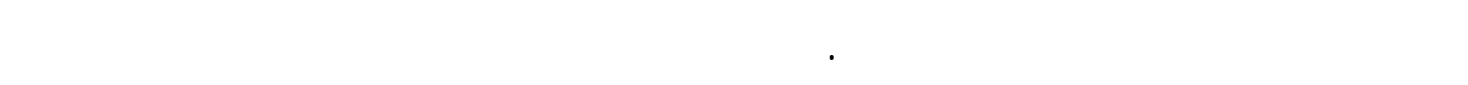

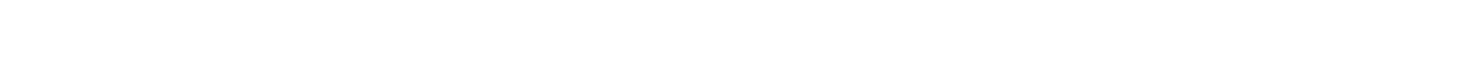

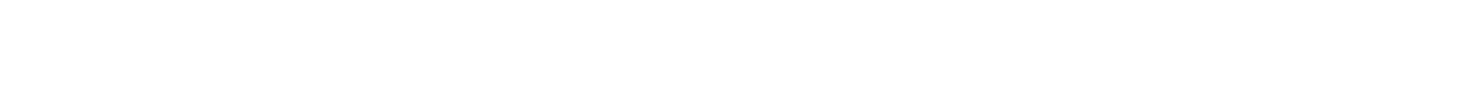

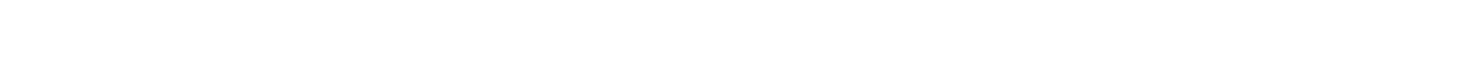

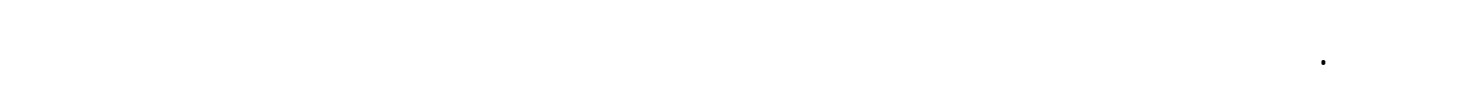

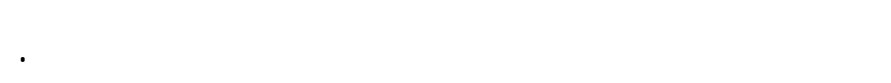




\begin{abstract}
The present study was conducted to investigate the effect of soybean seeds $(15 \mathrm{~g} / \mathrm{kg}$ diet $)$ for one month on blood picture, total cholesterol(TC), high density lipoproteins(HDL), low density lipoproteins(LDL), triglycerides (TG), glucose, alanine aminotrasferase (ALT) and aspartate aminotrasferase (AST) enzymes activity, glutathione(GSH), total proteins, albumin, globulin and body weight in ovariectomized rats(OVX). The rats randomly divided in to three groups (6 rats / group). The first group served as a control, the second group rats at one month aged bilateral ovariectomy were done, and the third group rats at one month aged bilateral ovariectomy were done, and after two months the rats treated with soybean seeds for one month. The result showed that a significant decrease in the total leucocytes count, HDL, GSH and globulin in ovariectomized group compared with control group, with no significant differences in PCV, $\mathrm{Hb}$, differential leucocytes count(DLC), total proteins, albumin and body weight. The current study demonstrated that a significant increase in T-C, LDL, ALT and glucose in ovariectomized rats group compared with control group.

Administration of soybean seeds caused a significant increase in total leucocytes count, globulin and body weight compared with ovariectomized group, and a significant decrease in T-C, TG, LDL and glucose compared with ovariectomized group. It could be concluded from this study that administration of soya beans seeds have a beneficial improving of some physiological and biochemical parameters in ovarictomized rats.
\end{abstract}

Keywords: soybean seeds, ovariectomized rats, blood picture, lipid profile.

Abbreviation: total cholesterol(T-C), high density lipoprotein(HDL), low density lipoprotein (LDL), triglyceride (TG), alanine aminotransferase (ALT), aspartate aminotrasferase(AST), glutathione(GSH), deferential leucocytes count (DLC), Ovariectomy(OVX).

\title{
Introduction
}

Interest in the physiological role of bioactive compounds present in plants has increased dramatically over the last decade, of particular interest in relation to the class of compounds known as the phytoestrogens(1). Phytoestrogens are define as naturally occurring, nonsteroidal, plant compound classified as isoflavones coumestrans and lignans, that are structurally and functionally similar to human estrogen 17-beta estradiol(2). Estrogen play an important role in the growth differentiation and function of many targets including the female and male reproductive system. Estrogen also has a variety of pharmacological function such as maintenance of bone mass, cardiovascular, and brain 
protection (3). The most likely cause for this difference is the deficiency of the ovarian hormone, especially estrogen. Hormone replacement therapy is often prescribed to suppress such estrogen-related diseases. While some salutary effects have been substantiated(4). Due to some sever side effects hormone replacement therapy soy derived are advertised as selective estrogen receptor modulators with only desired and no undesired estrogenic effect(5). Hormone replacement therapy is suspected to increase the risk of uterine bleeding $(6,7)$. Because of these undesirable side effects, start to seek more natural alternatives,such as the so-called phytoestrogens. These alternatives, include soybeans products that contain estrogen -like molecules such as diadzein and genistein. Soybean and soybean derived products have recently become common additives in health foods and beverages $(7,8)$. Soybeans have able to bind and activate estrogen receptor (9). Particularly, the binding affinity of estrogen receptor B (ERB) for the isoflavonoid genistein is $87 \%$ that for estradiol, and genistein activates ERB with high potency (10). Soybean are the richest food source of isoflavones, containing 1-2 $\mathrm{mg}$ of isoflavones per gram of soy protein, the isoflavones of soy are genistein, daidzein(11). Soybean are noteworthy for their high protein content, approximately $38 \%(12)$. They also contain $18 \%$ fat, primarily polyunsaturated fats and only small amount of saturated fats(13). 13\% of the soybean is made of soluble carbohydrates (sucrose, raffinose and others $15 \%$ insoluble carbohydrates $(11)$, and 14\%moisture, ash and miscellaneous compound. Other study observed that soybean treatment possess antidiabetic effect through decreasing levels of serum glucose and lipids in both normal and diabetic rats(14).

In current study was undertaken to characterized the effect of soybean seeds on some physiological and biochemical aspects in ovariectomized rats.

\section{Preparation of animals:}

\section{Materials and methods}

This study was performed at the animal's house of Veterinary Medical college -University of Mosul. Growing female albino rats at one month of age weighing (30-35g) were housed in polypropylene cages under condition of temperature $\left(22-25 \mathrm{c}^{\circ}\right)$ and lighting (12hours light/12hours dark). The rats were supplied a standard pellet diet and tap water ad libitum.

\section{Experimental design:}

Soybean seeds were purchased from the local market in Mosul. Eighteen growing female rats (one month age) randomly assigned to three groups of (6 rats /group). Group1: rats remained intact (as control) where 
as group 2: rats at age of one month bilateral ovariectomy (OVX) were done under general anesthesia using ketamine $(50 \mathrm{mg} / \mathrm{kg} \mathrm{B}$.W.) (KetalarPark Davis Company U.K.) and xylazine $(5 \mathrm{mg} / \mathrm{kg}$ B.W.) (Ceva Sante animal - Xylazine France) intraperitonium, operation were done by making incision in flank region and removed the ovaries using pointed scissor and suturing the skin by simple interrupted stitch. Rats were placed in clean cages and monitored until fully recovered from effect of anesthesia. Group 3: bilateral ovariectomy were done to the rats at one month and after two month started with treated with soybean seeds at dose $15 \mathrm{~g} / \mathrm{kg}$ diet (15) for one month. At the end of experiment blood samples collected into tubes contain anticoagulant (EDTA) for complete blood picture also blood samples were collected into clean dry centrifuge tubes allowed to clot, serum separated after centrifugation at $1500 \mathrm{rpm}$ for minute (16). The animals sacrificed and liver putted in ice normal saline for glutathione (GSH) estimation as describe by Moron et al.(17).

\section{Complete blood picture:}

- White blood cell count: they were counted per cubic millimeter of blood by hemocytometer, blood was diluted with Turk 's solution.

- Hemoglobin concentration: it determined by Sahli method $0.02 \mathrm{ml}$ of blood added to graduated tube contain $\mathrm{HCl}$, blood and $\mathrm{HCl}$ mixed and waited for 10 minutes, after that distilled water added drop by drop and mix after each addition until the color of the mixture become identical to standard of the comparator block, the hemoglobin value is obtain (18).

- Packed Cell Volume: determined by microhematocrite capillary tube and microhematocrite centrifuge (1200 circle/minute) then using microhematocrite reader to obtained PCV value as percentage (18).

Differential leucocytes count (DLC): thin blood film was prepared and stained with Wright stain(18) and counted 100 cell using Battlement method, calculated the percentage number of each of lymphocyte, neutrophils, basophils, eosinophils and monocytes.

\section{Biochemical analysis :}

Total cholesterol, high density lipoprotein, glucose, alanine aminotransferase and aspartate aminotrasferase enzyme activities and albumin were measured using colorimetric assay kit (Syrbio, Syria).

Triglyceride was measured using kit (bioMerieux, France). Total protein (Biuret method) as described by Wotton (19).

Statistical analysis:

All data were analyzed by one -way analysis of variance. The specific group differences were determined using Duncan multiple range test (20). The accepted level of significant was $\mathrm{p}<0.05$. 


\section{Results}

(Table 1) demonstrated that a significant decrease $(p<0.05)$ in total number of leucocytes in ovarictomized rats group compared with control group.

Administration of soybean seeds to the ovariectomized rats showed a significant increase in the total number of leucocytes and return the value to the control group. No significant differences between groups in the packed cell volume and hemoglobin concentration.

(Table 2) showed that no significant changes between groups in the differential leucocytes count.

(Table 3) demonstrated that a significant increased $(p<0.05)$ in the serum total cholesterol level in adult ovariectomized rats compared with rats of control group.

Administration of soybean seeds $15 \mathrm{~g} / \mathrm{kg}$ diet to the ovarictomized rats caused a significant decrease $(\mathrm{p}<0.05)$ in total cholesterol compared with ovariectomized group and return to the control group. Same Table revealed no significant changes in triglycerides level ovariectomized group compared with control value. Whereas ovariectomized rats treated with soybean seeds caused a significant decrease $(\mathrm{p}<0.05)$ in triglycerides level compared with ovariectomized group and the value return to control group. The data of ovariectomized rats showed a significant decrease $(p<0.05)$ in high density lipoproteins compared with control group. Treatment of the ovariectomized rats with soybean seeds did not affect significantly on high density lipoproteins compared with ovariectomized and control group. A significant increase $(\mathrm{p}<0.05)$ in low density lipoproteins in ovariectomized rats compared with control group. Administration of soybean seeds caused a significant decrease $(\mathrm{p}<0.05)$ in serum low density lipoproteins compared with ovariectomized group and return to the control value.

Table 1- Effect of administration of soybean seeds $(15 \mathrm{~g} / \mathrm{kg}$ diet $)$ to the ovariectomized rats on leucocytes number, PCV, $\mathrm{Hb}$

\begin{tabular}{||l|c|c|c||}
\hline \hline Treatment & $\begin{array}{c}\text { White blood } \\
\text { cells } \times 10^{3} / \mu\end{array}$ & $\begin{array}{c}\text { Packed cell } \\
\text { volume \% }\end{array}$ & $\begin{array}{c}\text { Hemoglobin } \\
\mathrm{g} / \mathrm{dl}\end{array}$ \\
\hline \hline Control & $\begin{array}{c}\mathrm{a} \\
8.62 \pm 1\end{array}$ & $\begin{array}{c}\mathrm{a} \\
30 \pm 0.54\end{array}$ & $\begin{array}{c}\mathrm{a} \\
13.9 \pm 0.2\end{array}$ \\
\hline Ovarictomized rats & $\mathrm{b}$ & $\mathrm{a}$ & $\mathrm{a}$ \\
$5.91 \pm 0.4$ & $33 \pm 1.22$ & $13.44 \pm 0.6$ \\
\hline $\begin{array}{l}\text { Ovarictomized rats }+ \\
\text { soybean seeds } 15 \mathrm{~g} / \mathrm{kg} \\
\text { diet }\end{array}$ & $\begin{array}{c}\mathrm{a} \\
9.07 \pm 0.7\end{array}$ & $\begin{array}{c}\mathrm{a} \\
31.8 \pm 1.01\end{array}$ & $\begin{array}{c}\mathrm{a} \\
\text { | }\end{array}$ \\
\hline \hline
\end{tabular}

- Values were expressed as means $\pm \mathrm{SE}$ from 6 rats /group.

- Values with different letters in column are significantly different $(\mathbf{p} \leq 0.05)$. 
Table 2- Effect of administration of soybean seeds (15 $\mathrm{g} / \mathrm{kg}$ diet) to the ovarictomized rats on differential leucocytes count.

\begin{tabular}{|c|c|c|c|c|c|}
\hline Treatment & $\begin{array}{c}\text { Lymphocytes } \\
\%\end{array}$ & $\begin{array}{c}\text { Neutrophils } \\
\%\end{array}$ & $\begin{array}{c}\text { Monocytes } \\
\%\end{array}$ & $\begin{array}{c}\text { Basophiles } \\
\%\end{array}$ & $\begin{array}{c}\text { Esinophils } \\
\%\end{array}$ \\
\hline Control & $\begin{array}{c}\mathrm{a} \\
65.8 \pm 1.2\end{array}$ & $\begin{array}{c}\mathrm{a} \\
29.4 \pm 4.7\end{array}$ & $\begin{array}{c}\mathrm{a} \\
0.8 \pm 0.3\end{array}$ & $\begin{array}{c}\mathrm{a} \\
0 \pm 0\end{array}$ & $\begin{array}{c}\mathrm{a} \\
0.3 \pm 0\end{array}$ \\
\hline $\begin{array}{l}\text { Ovarictomized } \\
\text { rats }\end{array}$ & $\begin{array}{c}\mathrm{a} \\
69 \pm 2.1\end{array}$ & $\begin{array}{c}\mathrm{a} \\
32 \pm 2\end{array}$ & $\begin{array}{c}\mathrm{a} \\
0.8 \pm 0.2\end{array}$ & $\begin{array}{c}\mathrm{a} \\
0.2 \pm 0.2\end{array}$ & $\begin{array}{c}\mathrm{a} \\
0.5 \pm 0.2\end{array}$ \\
\hline $\begin{array}{c}\text { Ovarictomized } \\
\text { rats }+ \text { soybean } \\
\text { seeds }(15 \mathrm{~g} / \mathrm{kg} \\
\text { diet }) \\
\end{array}$ & $\frac{\mathrm{a}}{68.2 .6 \pm 1.2}$ & $\begin{array}{c}\mathrm{a} \\
28.8 \pm 1.1\end{array}$ & $\begin{array}{c}\mathrm{a} \\
0.54 \pm 0.2\end{array}$ & $\stackrel{\mathrm{a}}{0.4 \pm 0.4}$ & $\stackrel{a}{0.4 \pm 0}$ \\
\hline
\end{tabular}

- $\quad$ Values were expressed as means \pm SE from 5 rats per treatment.

Table 3- Effect of administration of soybean seeds ( $15 \mathrm{~g} / \mathrm{kg}$ diet) to the ovariectomized rats on lipid profile.

\begin{tabular}{||c|c|c|c|c||}
\hline \hline Treatment & $\begin{array}{c}\text { Cholesterol } \\
\mathrm{mg} / \mathrm{dl}\end{array}$ & $\begin{array}{c}\text { Triglycerides } \\
\mathrm{mg} / \mathrm{dl}\end{array}$ & $\begin{array}{c}\text { High density } \\
\text { Lipoproteins } \\
\mathrm{mg} / \mathrm{dl}\end{array}$ & $\begin{array}{c}\text { Low density } \\
\text { Lipoproteins } \\
\mathrm{mg} / \mathrm{dl}\end{array}$ \\
\hline \hline Control & $\mathrm{b}$ & $\mathrm{ab}$ & $\mathrm{a}$ & $\mathrm{b}$ \\
& $85.5 \pm 1.6$ & $79.2 \pm 2.6$ & $55.5 \pm 1.4$ & $13.9 \pm 1.3$ \\
\hline $\begin{array}{c}\text { Ovarictomized rats } \\
\mathrm{a}\end{array}$ & $\mathrm{a}$ & $\mathrm{b}$ & $\mathrm{a}$ \\
& $106 \pm 3.9$ & $89.5 \pm 4.4$ & $50 \pm 1.6$ & $38.2 \pm 3.6$ \\
\hline $\begin{array}{c}\text { Ovarictomized rats } \\
\text { +soybean seeds }(15 \\
\text { g/kg diet) }\end{array}$ & $\begin{array}{c}\mathrm{b} \\
84.6 \pm 1.8\end{array}$ & $\begin{array}{c}77.8 \pm 2.9 \\
\mathrm{ab}\end{array}$ & $\begin{array}{c}53.5 \pm 2.2 \\
\mathrm{~b}\end{array}$ \\
\hline \hline
\end{tabular}

- Values were expressed as means \pm SE from 6 rats /group.

- Values with different letters in column are significantly different $(p \leq 0.05)$.

(Table 4) showed that a significant increase $(p<0.05)$ in serum glucose and alanine aminotransferase enzyme activity level in ovariectomized rats compared with control value.

Administration of soybean seeds to the ovariectomized rats resulted in a significant decrease $(p<0.05)$ in the level of serum glucose compared with ovariectomized group and return to the same value level of control rats, whereas alanine aminotransferase did not affect significantly. No significant changes between groups in the level of aspartate aminotransferase enzyme activity (Table 4). a significant decrease $(p<0.05)$ in the level of glutathione liver tissue concentration in ovariectomized rats group compared with control value. Whereas administration of soybean seeds to the ovariectomized rats did not affect significantly on the level of glutathione compared with ovariectomized group. 
Table 4- Effect of administration of soybean seeds ( $15 \mathrm{~g} / \mathrm{kg}$ diet) to the ovariectomized rats on glucose, alanine aminotransferase, aspartate aminotrasferase enzyme activities, glutathione levels.

\begin{tabular}{||l|c|c|c|c||}
\hline \hline Treatment & $\begin{array}{c}\text { glucose } \\
\mathrm{mg} / \mathrm{dl}\end{array}$ & $\begin{array}{c}\text { Alanine } \\
\text { Amimotraferase } \\
\text { Unit/ L }\end{array}$ & $\begin{array}{c}\text { Aspartate } \\
\text { Amimotraferase } \\
\text { Unit/ L }\end{array}$ & $\begin{array}{c}\text { Glutathione } \\
\mu \mathrm{mlg}\end{array}$ \\
\hline \hline Control & $\mathrm{b}$ & $\mathrm{b}$ & $\mathrm{a}$ & $\mathrm{a}$ \\
& $79.2 \pm 1.3$ & $13.3 \pm 0.6$ & $51.6 \pm 2.3$ & $6.9 \pm 0.1$ \\
\hline $\begin{array}{c}\text { Ovarictomized rats } \\
93.9 \pm 2.3\end{array}$ & $16.9 \pm 1.1$ & $55.4 \pm 1.9$ & $\mathrm{a}$ \\
$\begin{array}{c}\text { Ovarictomized rats }+ \\
\text { soybean seeds }(15 \\
\text { g/kg diet) }\end{array}$ & $\mathrm{b}$ & $\mathrm{ab}$ & $\mathrm{a}$ & $\mathrm{b}$ \\
\hline
\end{tabular}

- Values were expressed as means $\pm \mathrm{SE}$ from 6 rats /group.

- Values with different letters in column are significantly different $(\mathbf{p} \leq \mathbf{0 . 0 5})$.

No significant differences between groups in the levels of total proteins and albumin (Table 5). A significant decreased $(\mathrm{p}<0.05)$ in globulin level in ovariectomized rats compared with control group, but treatment with soybean seeds cause a significant increased in globulin level and return to a value level of control rats.

Table 5- Effect of administration of soybean seeds $(15 \mathrm{~g} / \mathrm{kg}$ diet $)$ to the ovariectomized rats on total protein, albumin, globulin.

\begin{tabular}{||c|c|c|c||}
\hline \hline Treatment & $\begin{array}{c}\text { Total protein } \\
\mathrm{g} / \mathrm{dl}\end{array}$ & $\begin{array}{c}\text { Albumin } \\
\mathrm{g} / \mathrm{dl}\end{array}$ & $\begin{array}{c}\text { Globulin } \\
\mathrm{g} / \mathrm{dl}\end{array}$ \\
\hline \hline Control & $\mathrm{a}$ & $\mathrm{a}$ & $\mathrm{a}$ \\
& $7.2 \pm 0.1$ & $4.2 \pm 0.2$ & $3 \pm 0.1$ \\
\hline Ovarictomized rats & $\mathrm{a}$ & $\mathrm{a}$ & $\mathrm{b}$ \\
& $6.6 \pm 0.4$ & $5 \pm 0.5$ & $1.6 \pm 0.2$ \\
\hline $\begin{array}{c}\text { Ovarictomized rats }+ \\
\text { soybean seeds } 15 \mathrm{~g} / \mathrm{kg} \text { diet }\end{array}$ & $\mathrm{a}$ & $\mathrm{a}$ & $\mathrm{a}$ \\
\hline \hline
\end{tabular}

- Values were expressed as means \pm SE from 6 rats /group. Values with different letters in column are significantly different $(\mathrm{p} \leq \mathbf{0 . 0 5})$.

No significant changes between groups in the body weight of animals at 90 days, whereas there is significant increase $(p<0.05)$ in the weight of rats at 120 days in ovariectomized rats which treated with soybean seeds (Table 6). 
Table 6- Effect of administration of soybean seeds $(15 \mathrm{~g} / \mathrm{kg}$ diet $)$ to the ovariectomized rats on weight.

\begin{tabular}{||l|c|c||}
\hline \hline Treatment & $\begin{array}{c}\text { Weight of animals } \\
\text { at 90 days }\end{array}$ & $\begin{array}{c}\text { Weight of animals } \\
\text { at 120days }\end{array}$ \\
\hline \hline Control & $\begin{array}{c}\mathrm{a} \\
79.6 \pm 2.1\end{array}$ & $\begin{array}{c}\mathrm{b} \\
156.2 \pm 7\end{array}$ \\
\hline Ovarictomized rats & $\begin{array}{c}\mathrm{a} \\
86 \pm 4.4\end{array}$ \\
\hline $\begin{array}{l}\text { Ovarictomized rats+ soybean } \\
\text { seeds } 15 \mathrm{~g} / \mathrm{kg} \text { diet }\end{array}$ & $\begin{array}{c}\mathrm{a} \\
93.8 \pm 6.9\end{array}$ & $223.4 \pm 8.2$ \\
\hline \hline
\end{tabular}

- Values were expressed as means \pm SE from 5 rats per treatment.

- Values with different letters in column are significantly different $(p \leq 0.05)$.

\section{Discussion}

Our study showed a significant increase in serum total cholesterol and low density lipoproteins and decrease in high density lipoproteins in ovariectomized rats. This results is in agreement with previous study (21) in ovariectomized rats and other studies $(22,23)$ in ovariectomized rabbits. This elevation of TC, LDL and decrease in HDL may be due to as a result of reduced estrogens, these hormone play an active role in the reduction of TC, LDL and increase in HDL (24), same study recorded an increase in TC and LDL and coronary artery disease in women after menopause (24).

It was evident from the results of present study that soybean seeds administration reduced LDL. Ali et al(25) reported similar results in rats This decrease may be due to the proteins content of soybean have a role in decrease cholesterol levels in blood, also affect other lipoproteins that transport it though transport it though increase synthesis protein part of this lipoprotein (26), or may be the flavonoids present in soybean lead to decrease cholesterol that lead to decrease low density lipoproteins level because its role in transport cholesterol. Another possible explanations include that soybean content 's of isoflavones serve as a natural selective estrogen receptor modulator and that exert an effect on lipid metabolism through their biological similarities to estrogen -receptor -dependent gene expression (27). Or isoflavones affect on cellular lipid homeostasis by the down -regulation of sterol-protein and its target genes in the liver (28). Present study demonstrated a significant increase in blood glucose in ovariectomized rats. Al-Suleman reported similar result in ovariectomized rabbit, in ovariectomized rats(29), in ovariectomized cow and buffaloes(30). This elevation of glucose may be due to the absence of estrogen hormones. 
In current study administration of soybean seeds reduced blood glucose concentration, this result agree with (29). Soybean seeds reduced glucose level due to inhibition of $\alpha$-glucosidase in the intestine that is responsible for split of disaccharide and polysaccharide (31). Also soybean seeds contain essential amino acid which cause stimulation of beta cell in pancreas to secrete of insulin, furthermore when administration of arginine alone to the rats stimulate secrete of insulin (32). The result of current study indicated a significant increase in alanine aminotransferase in ovarictomized rats, this study similar to recent study in ovariectomized rabbits(23). In present study demonstrated a significant decrease in the total leucocytes count this result similar to previous study done by (33), this decrease in total number of leucocytes in ovarictomized animals due to absence of estrogen (33). Kamada et al (34) demonstrated very severe changes in histology of bone marrow in ovariectomized rats and when treatment with 17B-estradiol cause an increase in number of leucocytes (35). In current study administrated of soybeans increase number of total leucocytes count. Di Silvestro and Supro (36) recorded that soybean contain antioxidants compounds, amino acids which can boost the immune system. Present study demonstrated a significant decrease in liver glutathione levels. This result agree with AbdulRahman, Al-Suleman $(21,23)$. Ovariectomy in rats cause a significant changes in the enzymatic antioxidants system including catalase, superoxide dismutase and nonenzymatic antioxidants (37). Estrogens are important in organized and stabilized of the level of tissue glutathione and inhibition of lipid peroxidation in the tissue (38). Improvement of body weight after soybean seeds treatment was demonstrated in current study. The possible mechanisms include the high percentage of protein, isoflavone, or fiber that increase metabolic processes in body (39), or may be due to that soybean have hypoglycemic activity (25) reversing lipid levels near to normal and improvement of body weight (40).

\section{Acknowledgements:}

This study was supported by the College of Veterinary Medicine, University of Mosul.

\section{References}

1) Cassid Y. A. Potential risks and benefits of phytoestrogen-rich diets. Int J Vitam Nutr Res., 73 (2):120-126 (2003).

2) Miniello V. L., Moro G. E., Tarantino M., Natile M., Granieri L. and Armenio L. Soy-based formulas and phyto-oestrogens: a safety profile. Acta Paediatr Suppl., 91 (441):93-100(2003). 
3) Ciocca D. R. and Roig L. M. Estrogen receptors in human nontarget tissues: biological and clinical implications. Endocrinol Rev., 16. 35-62(1995).

4) Timins J. K. Current issues in hormone replacement therapy. New Jersey Medicine., 101.21-27 (2004).

5) Wuttke W., Jarry H., Westphalens S., Christoffel V. and SeidloiaWuttke D. Phytoestrogens for hormone replacement therapy. J Steroid Biochem Mol Biol., 83 (1-5) 133-147(2002).

6) Fernandez E., Gallus S., Bosetti C., Franceschi S., Negri E. and LaVecchia C. Hormone replacement therapy and cancer risk: a systematic analysis from a network of case- control studies. Int $\mathrm{J}$ Cancer., 105: 408-412 (2003).

7) Humphries K. H. and Gill S. Risk and benefits of hormone replacement therapy: The evidence speaks. Can Med Assoc J., 168:100-110(2003).

8) Benassayag C., Perrot-Applanat M. and Ferre F. Phytoestrogens as modulators of steroid action in target cells. Chromatogr., 777:233248. (2002).

9) Beck V., Rohr U. and Jungbauer A. Phytoestrogens derived from red clover: an alternative to estrogen replacement therapy. J Steroid Biochem Mol Biol., 94:499-518.(2005).

10) Kuiper G. G., Lemmen J. G., Carlsson B., Corton J. C., Safe S. H., Van der Saag P. T. and Van der Burg B. Interaction of estrogenic chemicals and phytoestrogens with estrogen receptor B. Endocrinology., 139.4252-4263(1998).

11) Haytowitz D. B., Matthews R. H. "Legumes and legumes products" Washington DC.US. 1-156. (1986).

12) Linscheer W. C. and Vergroesen A. J. Lipids In: Shils M. E., Olson J. A and Shike M. eds "Modern nutrition in health and disease" $8^{\text {th }}$ ed. Philadelphia: lea and Febiger. (cited by Anerson 1999). 47-88 (1994).

13) Anonymous Final report of amended safety assessment of PEG5,10,25,30 and 40 soy sterol. Int J Toxicol., 2:23-47(2004).

14) Aziz O. H. The effect of soybean seeds on some biochemical parameters in normal and alloxan-induced diabetic rats. MSc. Thesis College of Veterinary Medicine, University of Mosul. (in Arabic) (2005).

15) Stephen A., Ryan D., Mark F and Amy G. Adult-only exposure of male rats to a diet of high phytoestrogen content increases apoptosis of meiotic and post-meiotic germ cells. Reproduction 133:11-19 (2007).

16) Fox J. G., Cohen B. J. and Loew F. M. "laboratory Animal Medicine" Academic press London, U. K. 19-20.(1984) 
17) Moron M. S., Depierre J. W. and Mennervik B. Level of glutathione, glutathione reductase and glutathione S-transferase activities in rats lung and liver. Biochem Biophys Acta., 582-678. (1979).

18) Jain N. C ED. "Schalm s Veterinary hematology" USA. Lea and Febiger. 276-282 (1986).

19) Wotton I. D. P. "Microanalysis Medical Biochemistry"..$^{\text {th }}$ ed., Churchill Livingston Edinburgh and London 156-158(1974).

20) Petrie A. Watson P. "Statistic for veterinary and animal science" Blackwell Publishing Company.(1999).

21) Abdul-Rahman S. Y. Effect of starvation and experimental diabetes mellitus on glutathione and lipid peroxidation in tissues rats. Doctor's dissertation. College of Veterinary Medicine, University of Mosul (in Arabic) (1995).

22) Shrif R. S. A. Effects of apple cider vinegar and simvastatine on blood lipid profile in adult female rabbits. Doctor's dissertation College of Veterinary Medicine, University of Mosul (in Arabic) (2003).

23) Al-Suleman Agha R. A. A. Effect of Garlic (Alliums Sativum) extracts as antioxidants in female rabbits exposed to oxidative stress. Doctor's dissertation. College of Veterinary Medicine, University of Mosul (in Arabic) (2007).

24) Vander A., Sherman J. and Luciano D. "Human Physiology": The mechanisms of body function. $7^{\text {th }}$ ed. Mc Craw-Hill Co. Inc., New York (1998) p609.

25) Ali A. A., Velasques M. T., Hansen C. T., Mohammad A. I. and Bhathna S. J. Effect of soybean isoflavones, probiotics and their interaction on lipid metabolism and endocrine system in an animal model of obesity and diabetes. J Nutr Biochem., 15 (10):585-590 (2004).

26) Burger H.G. and Teede H.J. Endocrine changes in the per menopause. In Lobo R.A., ed.Treatment of the postmenopausal women.2 nd ed. London :Lippencott Ravenwood 52-68(1999).

27) Gruen D.G. and Silverstein D.K. Usual dietary isoflavones intake is associated with cardiovascular disease risk factor in postmenopausal women. J Nutr 131:1202-1206(2001).

28) Shukla A., Brandsch C., Bettzieche A., Hirchae F. and Stangl G.I. Ederk. Isoflavone poor soy protein alters the lipid metabolism of rats by SREBP-mediated down -regulation of hepatic genes. J Nutr Biochem., 18(5)313-321 (2007).

29) Aziz B. N. Certain biochemical changes associated with starvation,oxidative stress and experimental diabetes mellitus in rats :Effect of some medical plants and female sex hormone. Doctor's 
dissertation.College of Veterinary Medicine, University of Mosul (in Arabic) (1999).

30) El-Tohamy M. M., Ahmed W.M. and Abdoon A.S.S. Relationship between blood composition and ovarian inactivity in cows and buffaloes and trials for possible treatment. J Union Arab Biol Cario., 6;181-192(1996).

31) Fujita H., Yamagami T. and Ohshima K. Long -term ingestion of a fermented soybean derived touch -extract with $\alpha$-glucosidase inhibitory is safe and effective in human with borderline and mild type -2 diabetes.J Nutr., $131: 2105-2108$ (2001).

32) Lavigne C., Martte A. and Jacques H. Cod and soy proteins compared with casein improve glucose tolerance and insulin sensitivity in rats. Am J Physiol Endocrin Metab., 278:491-500. (2000).

33) Hassan A A. Effect of ovarictomy on certain blood constituents in adult rabbits. Iraqi Journal of Veterinary sciences, (17)1 (2003) 23p.

34) Kamada M., Irahara M., Maegawa M., Yasui T., Yamano S. Yamada M. and T ezuka M. B cell subsets in postmenopausal women and the effect of hormone replacement therapy. Maturitas, 37 (3)173-179(2001).

35) Keller E.T., Zhang J. and Yooz Q. The impact of chronic estrogen on immunology parameters in the ovarictomized rhesus monkey (Macaca mulatta) model of menopause. J Rep Immunol., 50 (1)4155(2001).

36) Di Silvestro R. and Supro. Soy protein beverage produces antioxidant effect in athletes and weekend warriors, whey protein did not. Journal of Nutraceutical, functional and Medical Foods. 3. (2000).

37) Gomes-Zubeldia M. A., Hernandez R., Vigura J., Arbues J.J., Aparicio A. and Millan J.C. Effect of bilateral ovarictomy and ovarian steroid hormones on the antioxidant systems and plasma malodialdehyde level in wister rats. Endocr Res., 26:97-107. (2000).

38) Rificia V. A. and Khachdurian A. K. The inhibition of low density lipoprotein oxidation by 17-beta estradiol. Meta Clin Exper. 41(10)1110-1114.(1992).

39) Hemansen K., Ndergard M., Lars H., Cartensen M. and Brock B. Beneficial effects of a soy based dietary supplement on lipid levels and subjects. Dia Care., 24:228-233. (2001).

40) Bhathena S. J., Ali A. A., Haudenschild C., Latham P., Ranich T., Mohamed A. L., Hasen C.T. and Velasques M.T. Dietary flaxseed meal is more protective than soy protein concentrate against hypertriglyceridemia and steatosis of the liver in an animal model of obesity. J Am Coll Nutr., 22(2):157-164 (2003). 